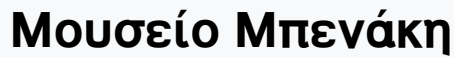

Tóp. 1, Ap. 11-12 (2012)

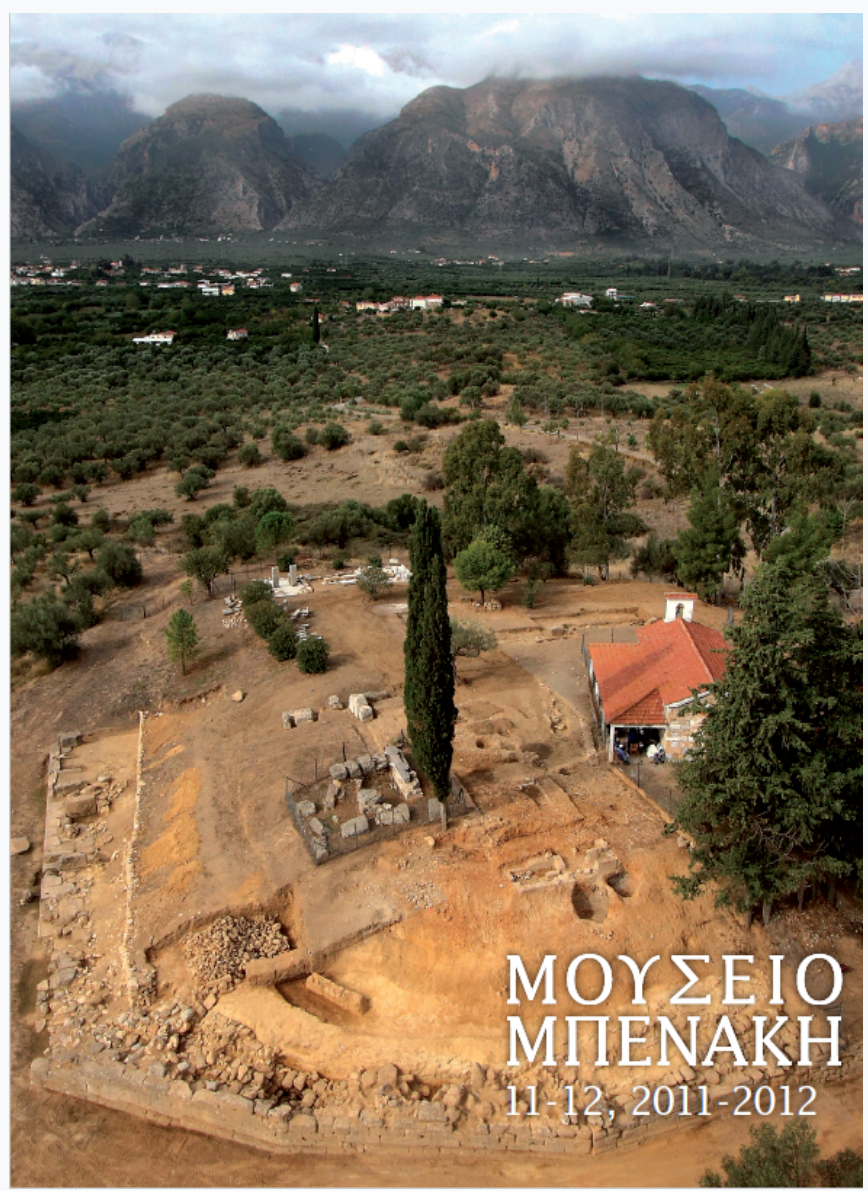

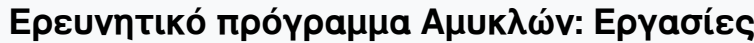 2005-2010}

Stavros Vlizos

doi: 10.12681/benaki.17772

Copyright $@ 2018$, Stavros Vlizos

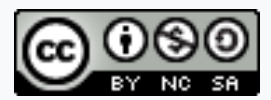

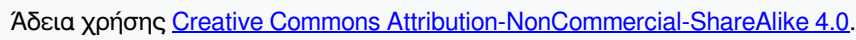

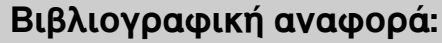

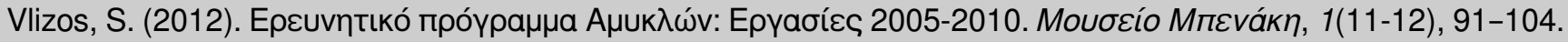
https://doi.org/10.12681/benaki.17772 


\section{Amykles Research Project: Excavation Works 2005-2010}

\section{N EPTEMBER STUDIES AND RESEARCE in} the Spartan Sanctuary of Apollo Amyklaios commenced (fig. 1). One of the urgent tasks of the project was to survey the Agia Kyriaki hill and the surrounding area in detail and to record in the new plans the evidence surviving from previous research carried out by Ch. Tsountas (1890/91), A. Furtwängler (1904), E. Fiechter (1907) and E. Buschor (1925). The existing condition of the archaeological site was mapped and the surviving parts of the krepis of the temple/Throne, of the Peribolos as well as the later church of St Kyriaki were documented by measured drawings.

Most of the in-situ architectural members of the temple/Throne and the Altar, which were either stacked in a pile of stones or dispersed in various places and on the slopes of the hill, were drawn, studied, photographed and identified.

All the architectural members from the monuments of the Sanctuary were gathered, sorted into categories and fenced inside the archaeological site and the already expropriated area (fig. 2). Thus, any further deterioration of the marbles' surface had been avoided and their protection was secured.

Many architectural members of the temple/Throne and the Altar, which were incorporated in the fabric of the churches in modern Amykles, as well as in the nearby communities, were located, photographed and temporarily recorded.

Lastly, photographing, drawing and studying those architectural members originating mainly from the temple/Throne presently kept in the internal courtyard of the Sparta Archaeological Museum began.
Although the timeframe of the first phase of research was limited, the results can be characterised as absolutely positive. Needless to say that, apart from the protection of the material in situ, many members from the upper structure of the buildings of the Sanctuary, which were not included in the publications of E. Fiechter [Fiechter 1918] and W. von Massow [Buschor - von Massow 1927], were discussed.

In 2006 the continuation of the Peribolos was sought in the north and the southwest part of the Sanctuary, with the cleaning and the investigation of three trenches opened in sectors A2, B2, N8 (see map 1) by E. Fiechter (1907) and E. Buschor (1925). During this work it was confirmed that the function of the Peribolos was essentially that of a retaining wall. It was constructed to a height of approximately $7 \mathrm{~m}$, in order to retain the large fills of the hill so as to facilitate the construction of the temple/Throne of Apollo at the top. With regard to the continuation of the course of the Peribolos to the southwest (A2), the conclusions of earlier excavations were confirmed. At this point, roughly $5 \mathrm{~m}$ to the north (B2), the west end of a probably previous wall was revealed, a precinct wall perhaps, with parallel direction and corresponding orientation. The investigation of the north part to the west $(\mathrm{N} 8)$ confirmed the continuity of its course, but the direction it followed was still to be determined.

The built bench in the portico of the hilltop church of St Kyriaki was dismantled and 20 architectural members of the Throne and the Altar were retrieved, which were transported to the fenced space for protection. The dismantling of the bench revealed a large number of architec- 


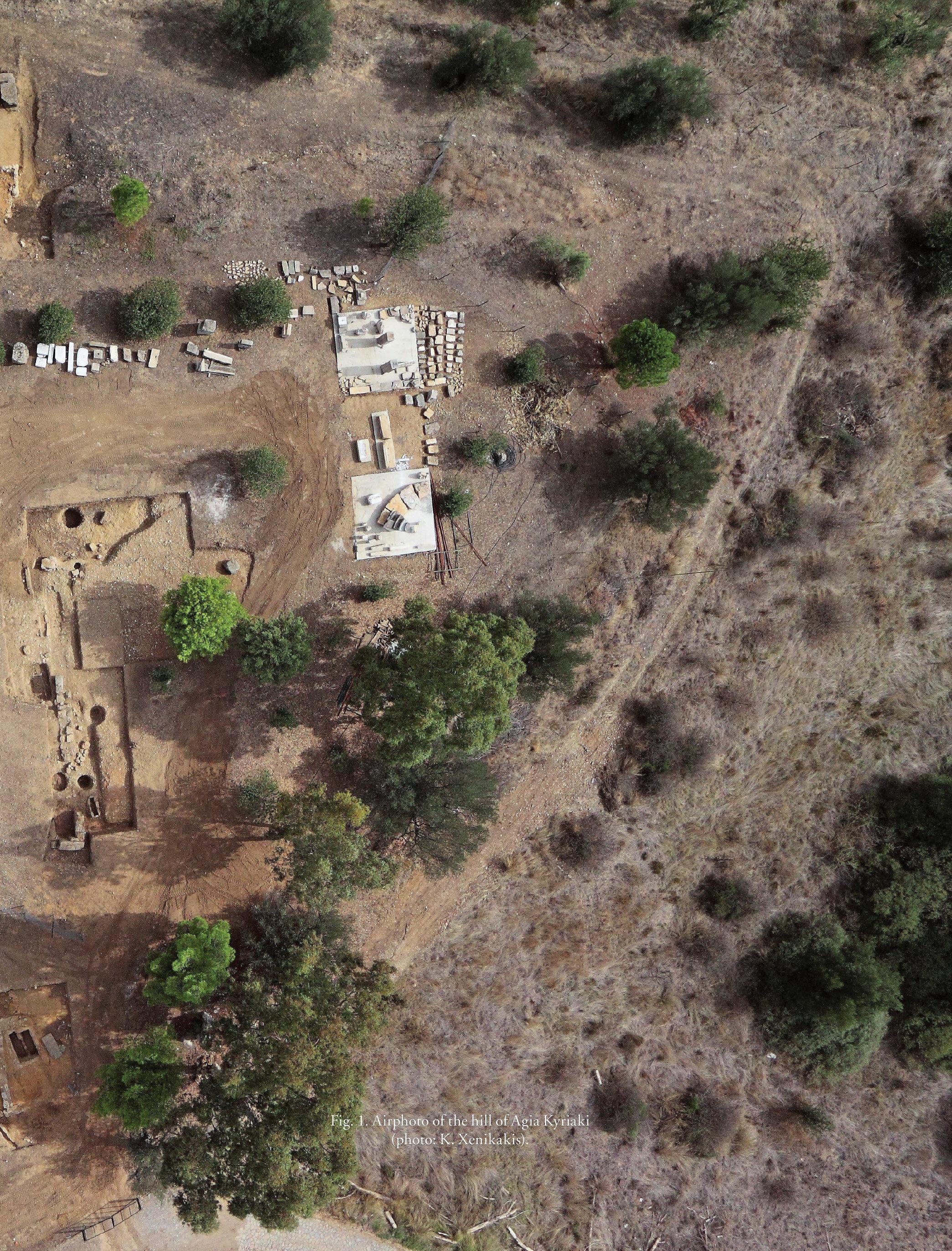




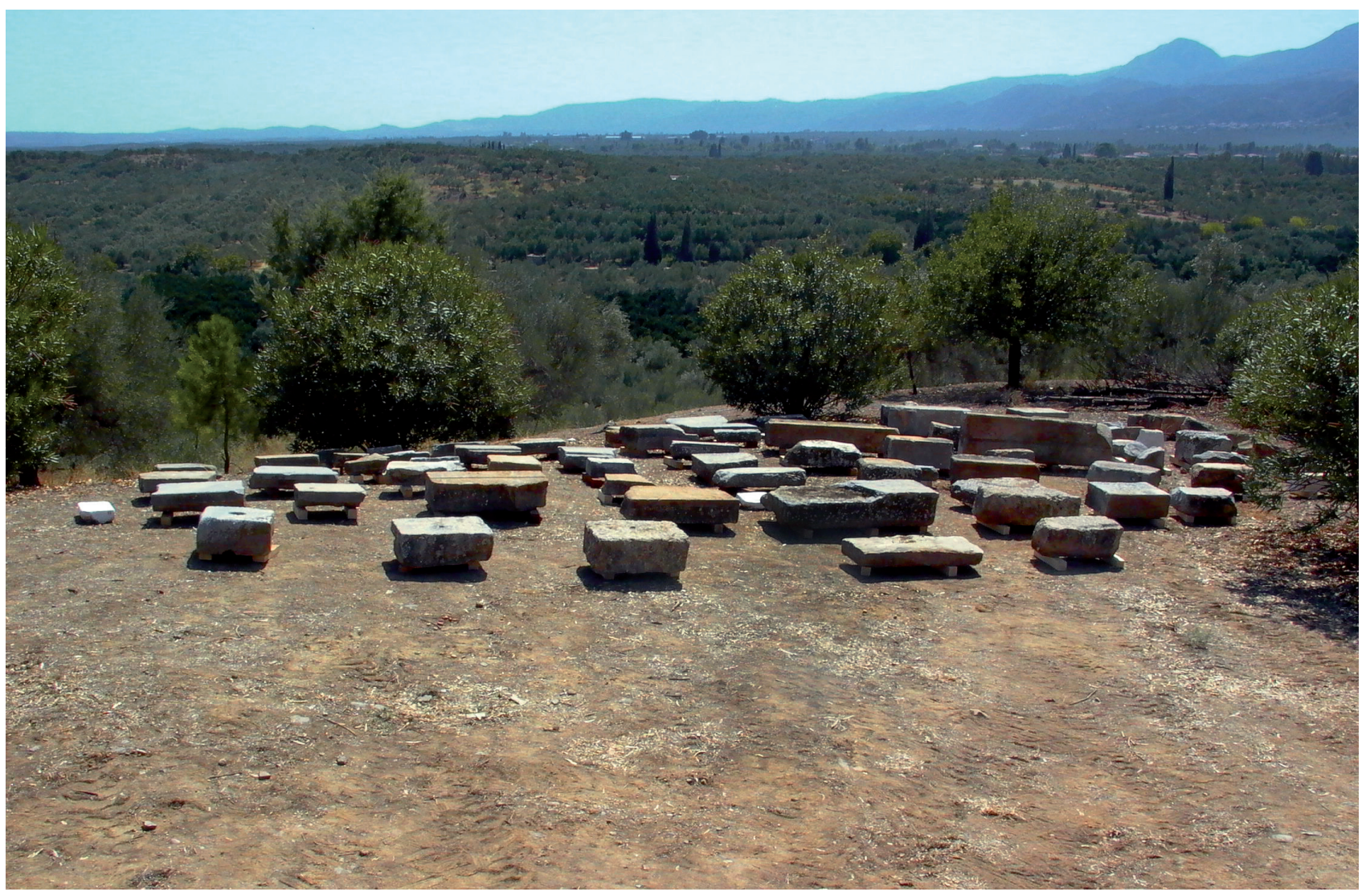

Fig. 2. Fenced area with architectural members (photo: S. Vlizos).

tural members in the lower part of the wall of the church, built into the masonry in a second use. This called for the removal of the plaster and the careful cleaning of the exterior surface. The church of St Kyriaki was built in the 1920 's, with many of the marbles uncovered in Fiechter's excavations (1904 and 1907), after the demolition of the earlier church, which covered the surviving part of the Throne's crepis. The documentation, photography and drawing of all the architectural members incorporated in the wall commenced.

The new architectural members located and assembled during the works of 2006 fill-in, together with the already studied material, the drawings of the circular stepped construction of the Altar, which Manolis Korres had led during the first phase of research in 2005 when less material was available.

The systematic documentation, measurement of drawings and photographing the architectural members from the Throne and the Altar, gathered by now in the fenced area on Agia Kyriaki hill and in the internal courtyard of the Sparta Archaeological Museum, was continued.

Manolis Korres located and made measured drawings of two monumental bases from the Throne in the form of a lion's paw, which supported the lid of a Roman sarcophagus in the garden of the Sparta Archaeological Museum (fig. 3). These new discoveries reinforced the indications deduced from other architectural members that the temple/Throne designed by Bathykles was in the form of a monumental seat.

The search for other architectural members from the monuments of the Sanctuary continued in the wider area of Sparta as well as in the storerooms of the archaeological site of Mystras.

In 2007 the entire course of the monumental retaining wall ("Peribolos") was revealed on the south side of the Sanctuary (see map 1). Its east side was cleaned and its end was sought at the north side (Sector $\Xi 7$ ), where, however the excavation was not completed. Concurrently, 


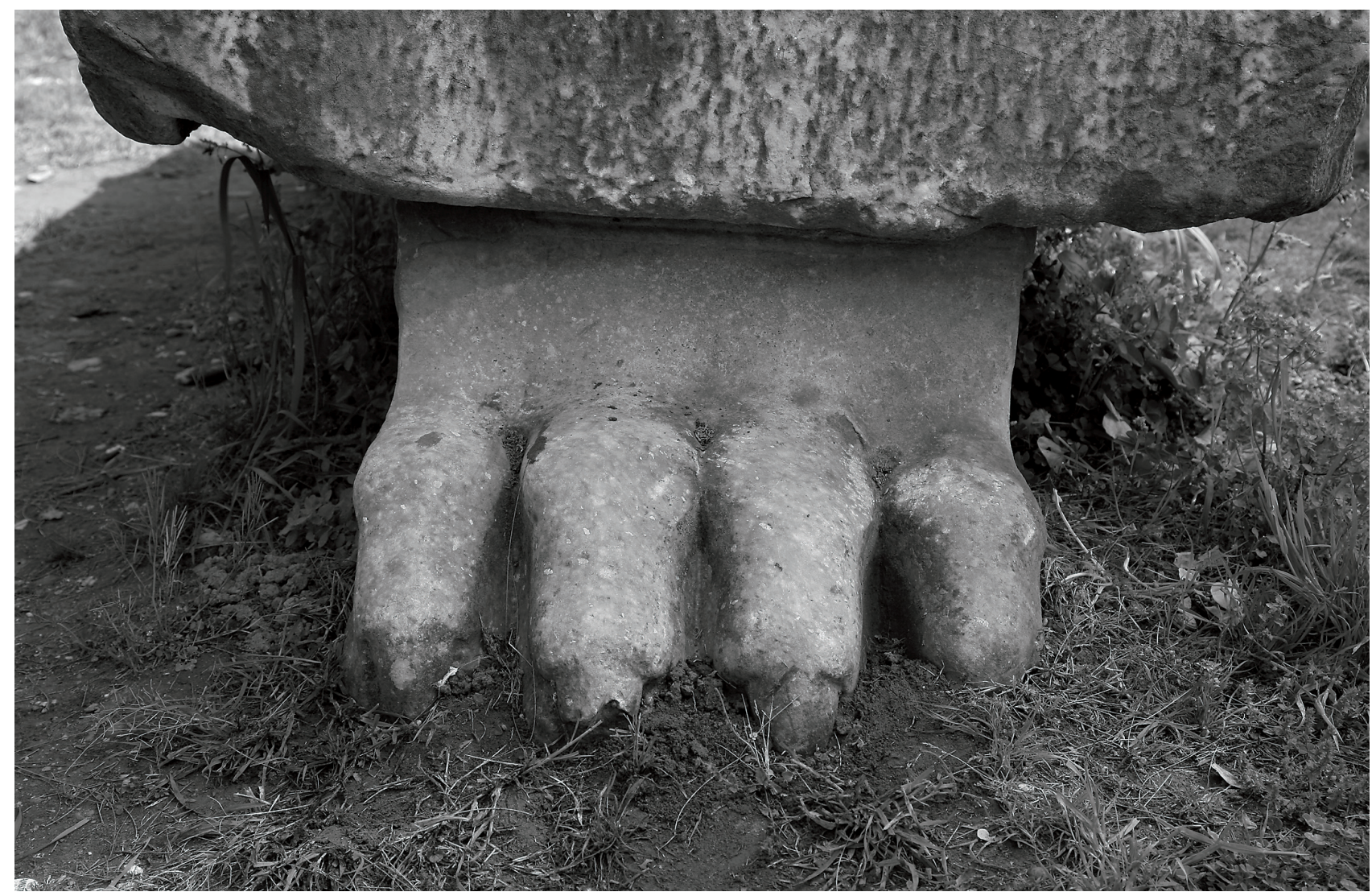

Fig. 3. Bases in the form of a lion's paw (photo: S. Vlizos).

the thickness and structure of this wall in its upper courses was revealed in sectors A3-A8. In the course of removing the landfill at this point, copious sherds of pottery, mainly of the Geometric period, were found, as well as two bronze statuettes of a standing male figure, of the same period. It was confirmed that later repairs had been made on the east side of the Peribolos, using lime plaster, clay and small stones.

During investigation of sectors $\mathrm{B} 3, \mathrm{\Gamma} 2-3$ and $\mathrm{B} 5$, the existence of a hitherto unknown retaining wall was confirmed. Built of rude stones and 1.80-2.00 $\mathrm{m}$ in depth, it probably dates back to the late Geometric period, as this is deduced from the large quantities of sherds found in its fill. Its west end had been uncovered for a length of $1.50 \mathrm{~m}$ in 2006. The large quantity of stones found on both its inner and outer faces indicates that it was a sizeable construction. As investigations in sector B5 have shown, its course slightly curves at this point in order to end at the southeast corner of the outer "Archaic" Peribolos.
The documenting, photographing and measured drawing of the architectural members incorporated in the fabric of the church of St Kyriaki, as well as of architectural material from the monuments of the Sanctuary, residing now in the Sparta Archaeological Museum, continued. Photographing of the bronze findings from earlier excavations was completed both in the National Archaeological Museum, Athens, and the Sparta Archaeological Museum.

A collaboration began with Professor Yannis Pikoulas on searching for the access route and road that connected the Sanctuary with ancient Sparta.

In 2008 the measured drawing and the architectural study of the so far excavated part of the monumental external Peribolos was completed. The aim of these works was, inter alia, the possibility of a future partial restoration, and the detailed architectural study. Concurrently, excavations to find the northwest end of this wall continued. In this sector $(\Xi 7)$, the last surviving course of stones was put back in place on the preserved part of the foundation. 


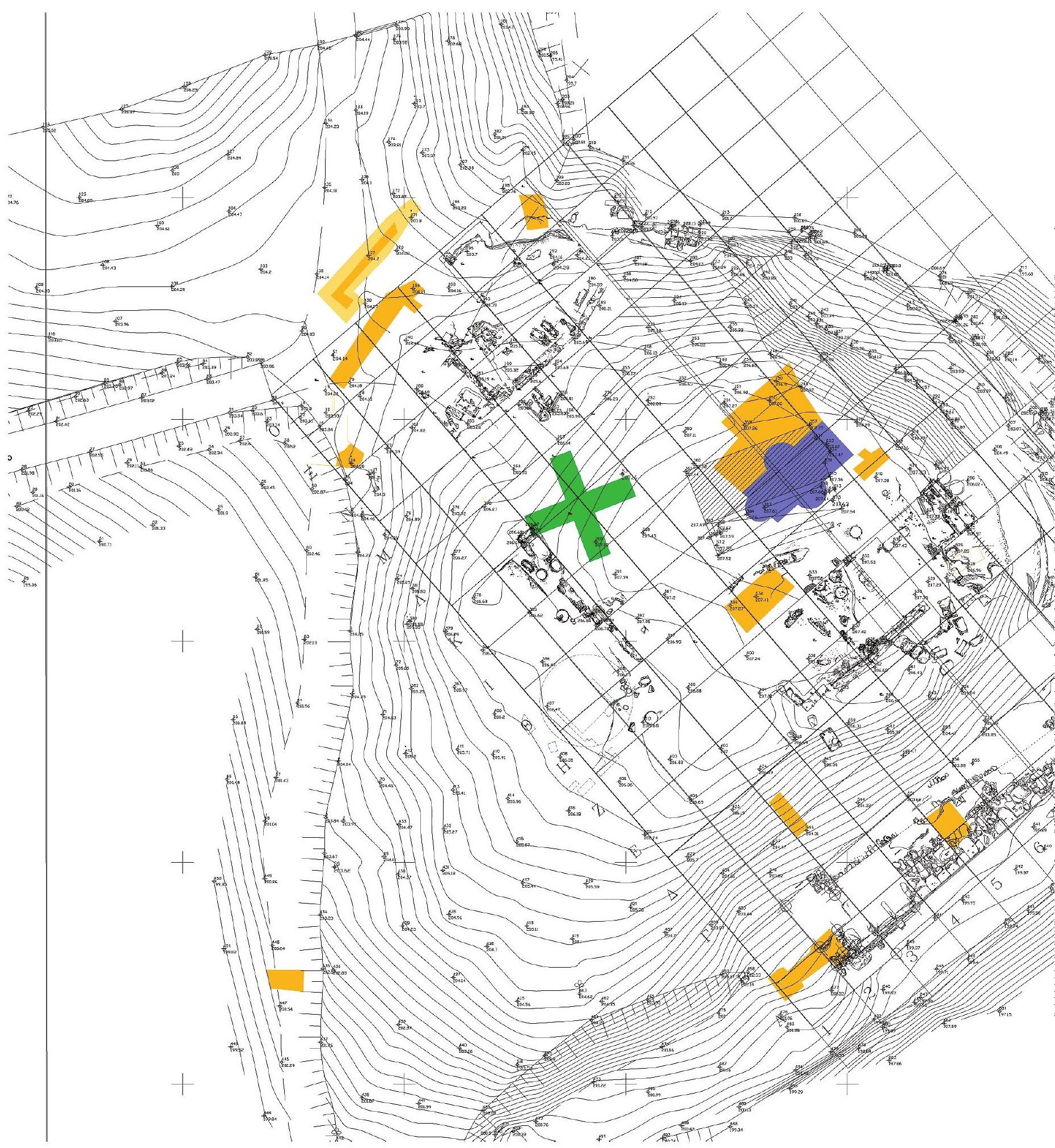

Map 1. The Sanctuary in 2010 (drawing: T. Bilis - M. Magnisali). 


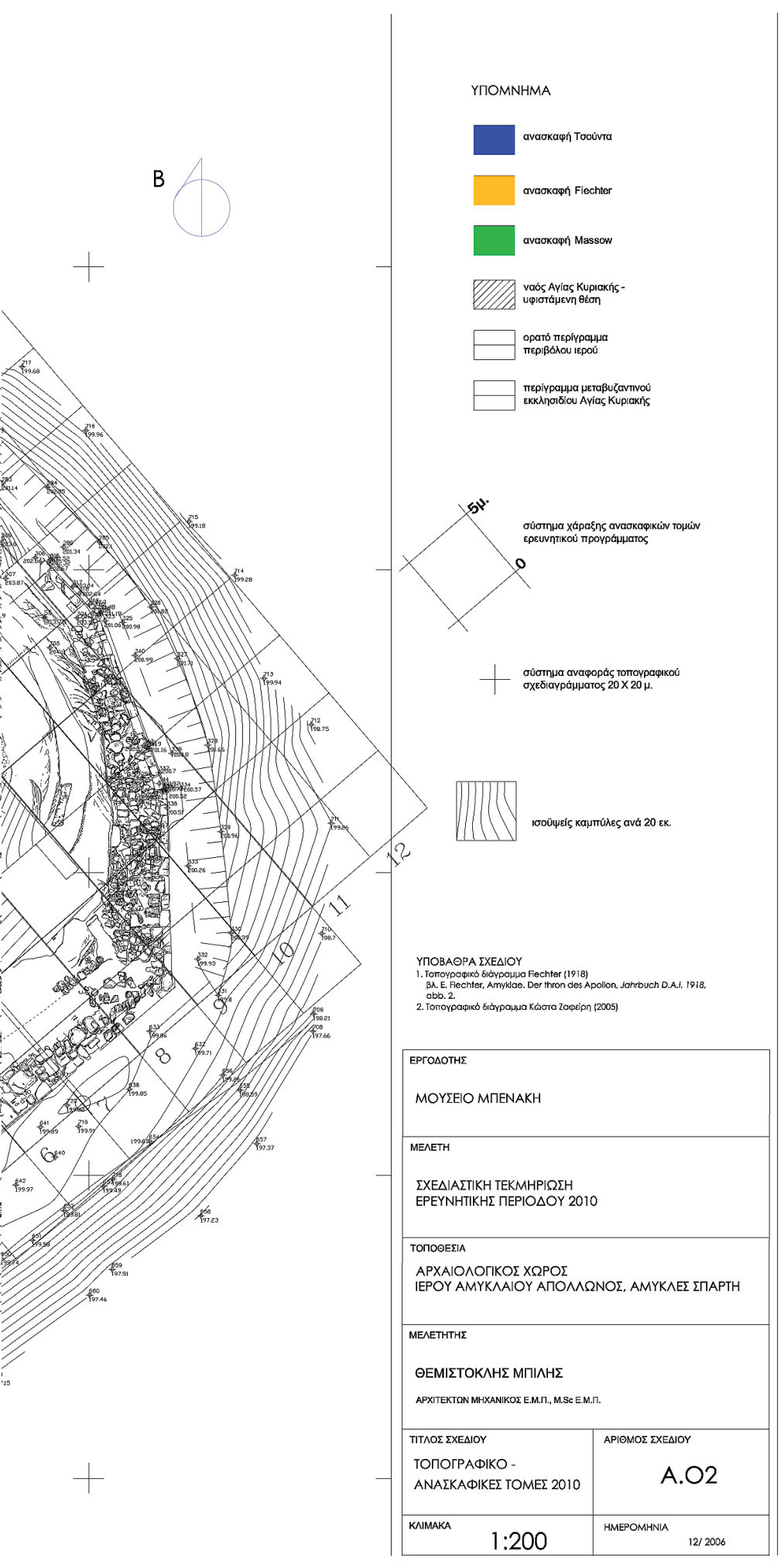

Located in the same area (Sectors N3, $\Xi 3-4)$ were traces from later constructions (see map 1), a cistern and a drain in which the lower half of a Late Roman inscribed herm had been used as building material, and part of the stylobate of an Archaic Doric colonnade, from the architectural members of the temple/Throne of Apollo.

The excavation was completed on the south side of the Sanctuary, aimed at revealing the previous, also monumental, internal retaining wall of the Geometric period, of length $30 \mathrm{~m}$ and thickness 1.80-2.00 m. During removal of the fill, apart from the abundance of pottery, mainly of the Geometric period, a large number of bronze objects of the same period were found (e.g. idols of a female figure and a bull, a miniature axe and a pin).

Systematic checking of the dump from Tsountas's excavations, which ran along the east side of Agia Kyriaki hill, at a distance of $5 \mathrm{~m}$ from the external Peribolos, was completed. With these works, a path 3.00-8.00 m wide was formed, suitable even for the occasional visit and tour of the archaeological site. From the sieving of the soil, several finds were retrieved, among them a bronze bowl (phiale), fragments of roof tiles with stamped inscriptions in which traces of the words $\mathrm{A} \Pi \mathrm{O} \Lambda \Lambda \Lambda \Omega \mathrm{NO} \Sigma$ EN AMYK $\Lambda$ AIOI can be detected, as well as parts of glass vessels from the Roman period.

The measured drawing, photographing and documenting of the architectural members incorporated in the fabric of the church of St Kyriaki and deposited in the courtyard of the Sparta Archaeological Museum continued.

The works on locating and identifying the quarries from which the marble structural elements of the buildings in the Sanctuary came were completed under the supervision of Prof. G. Kokkorou-Alevras. Specifically, there were two quarries on Mt Taygetos, at the localities "Gynaika" and "Platyvouni".

The works carried out in 2009 were focused on locating possible traces (cuttings) of the foundation of the Throne of Bathykles in sectors E, H 4-9 (see map 1). Due to the particularly disturbed area and the absence of thick deposits, the survey was exceptionally careful, in order to locate and investigate the earlier excavation trenches opened by Ch. Tsountas (1890) and E. Fiechter (1907). Six shallow, unfurnished pit graves were found, of dimensions approximately $1.75 \times 0.55 \mathrm{~m}$. Two likewise unfurnished tombs of dimensions $3.00 \times 2.30 \mathrm{~m}$ 
were also found, each comprising two chambers, as well as a further six empty circular pits of dimensions $1.20 \times 0.60$ $\mathrm{m}$, in two of which two obsidian flakes were found. An intact Early Helladic vase was collected from the fill and without context.

Investigations were continued in the northwest part of the hill and in sectors M4, N3-7, $\Xi 3, \Xi 5$, with the further excavation of the remains from Late Antique constructions brought to light the previous year (see map 1). Traces of walls and of later constructions were revealed, along with two unfurnished cist graves, of dimensions $1.70 \times 0.55 \mathrm{~m}$. The capstone and the walls of one grave consisted of parts of architectural members from the Throne of Apollo, from which resulted, for the first time, two intact architectural members of the monument (one dokis and one voluminous orthostat). Bones from eight skeletons were found inside the grave and permission was requested to transport these to the Archaeometry laboratory in Kalamata, in order to acquire anthropological and other information under the supervision of Prof. N. Zacharias.

The conservation and repair of broken parts from five architectural members of the Throne gathered at the archaeological site was completed. At the same time a programme of test placements of the architectural members in certain ensembles of the monument was initiated. The aim of this work was the certain identification of the scattered material and its correlation with the extant ruin of the Throne. This work resulted in new data for the study of the representation of the Throne. Members from the steps of a colonnade and the floor of the pteron were placed in groups, as well as of one wall of the monument with its euthynteria. Also, a test placement was made of correlated stones of the circular stepped altar. Lastly, a model of the profile of the bases in the form of a lion's foot was made and thus these particular architectural members were correlated with the steps of the Throne.

The programme of immediate measures of preventive conservation of the Geometric Peribolos was completed. This was mandatory for the direct protection of the ruin, which was frail and exposed to the environmental conditions of the area because of its construction and its position on the hill slope.

The documenting, measured drawing and photographing of the new excavation trenches, of the architectural members as well as of this season's finds continued along with the digitalisation of architectural drawings.
A geodetic or total station was used to create a dense network of benchmarks on the revealed remains, and the grid of the excavation sectors was applied in the field.

During the study of the limestone blocks of the colossal pedestal that supported the $13 \mathrm{~m}$-high cult statue of Apollo which had been reused in a later building (Sectors $\Delta$-E 4 , 6-7), bronze nails that held in place the metal plates which adorned the exterior of the construction were located. The stones were drawn in large scale, resulting in the more detailed approach to the form of the dismembered pedestal of the cult statue (fig. 4).

The measured drawing, photographing and documenting of architectural members incorporated in the fabric of the church of St Kyriaki, as well as of the members in the storeroom of the Sparta Archaeological Museum, continued. For the church in particular, it should be noted that there are over 60 fragments in its walls. Many of them had been measured by E. Fiechter, the first scholar involved with the Throne, and had been included in his study of its representation.

A cadastral table, essential for buying the properties surrounding the archaeological site today, was compiled, aimed at the new mapping of the limits of the archaeological site, its protection and its enhancement. Steps were taken to purchase two properties, approximately 5 acres in total, which border the archaeological site to the northeast.

In the framework of research aimed at locating further architectural members from the buildings of the Sanctuary, visits to sites of Byzantine and Post-Byzantine monuments in the wider area continued. In accordance with the decision of the Ministry of Culture regarding this year's work, the plaster from the small church of St Nicholas at Amykles was removed and repositioned again, leaving visible only the architectural members certainly from the monuments of the Sanctuary. Stones from the Throne and the Peribolos of the Sanctuary were located and documented, and measured drawings were made of the outside of the small church.

In 2010 the surface of the top of Agia Kyriaki hill was surveyed systematically in sectors $\mathrm{H}-\Theta 1-2$, with the aim of locating possible cuttings for the foundation of the circular stepped Altar (see map 1). As in the case of the temple/Throne the stratigraphy of the area was also badly disturbed, due to the earlier excavations by $\mathrm{Ch}$. Tsountas and Ernst Fiechter. The volume of soil removed, ranging in thickness from $0.20 \mathrm{~m}$ to $1.00 \mathrm{~m}$, belonged entirely to a 


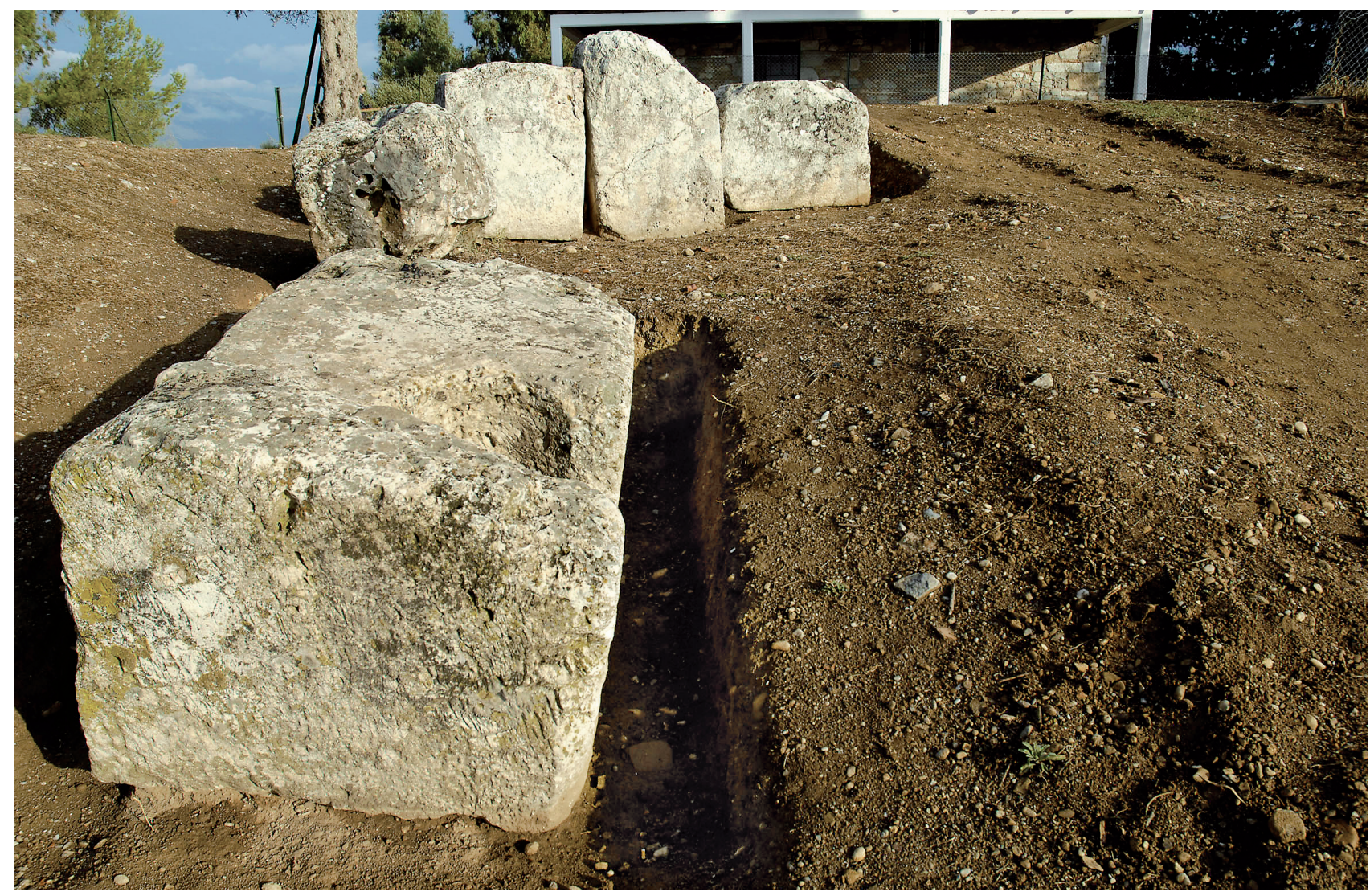

Fig. 4. Limestone blocks of the colossal pedestal of the cult statue of Apollo (photo: S. Vlizos).

layer of more recent fill, with many modern objects, such as nails, fragments of roof tiles, pieces of lime plaster and shells from bullets. Under this fill and over the whole excavated area, a compact layer of pebbles was revealed, in which no traces from the foundation of the altar are preserved. However, just as in the area of the temple/Throne, which was investigated last year, it was ascertained that this layer represents the upper level of the bedrock of the hill. Nonetheless, for the present the thickness of the overlying layer has not been verified. Along the east limit of sectors $\mathrm{H}-\Theta 1-2$ and at a distance of roughly $0.20 \mathrm{~m}$ to the west, some of the lowest courses of stones and traces of the foundation of a wall orientated north-south were found.1 Its construction with large limestone blocks in second use and lime plaster as mortar, suggests a dating in the Byzantine period. The north end was located in the northeast corner of sector K2, where the excavation was extended to include also sector I2. As was verified in sector K2, this wall is founded on two of the three empty circular pits that were found there, together with an empty cist grave. The excavated part of the wall is $20 \mathrm{~m}$ long, $0.40-0.60 \mathrm{~m}$ wide and of maximum preserved height $1.10 \mathrm{~m}$.

Between this wall and the east edge of sectors $\mathrm{H}-\Theta 2$, three destroyed burials were located, of which only one partly preserves walls of rude stones. A little further to the west, two more circular empty pits were excavated, similar to the seven that had been found between the crepis of the Throne and the church of St Kyriaki during the works in the last few years. A fragment of an ivory plaque with representation of a female figure, of the Archaic period, was recovered from the recent fill of the southernmost pit. This is an exceptionally important find, the first known one of this category, which obviously had been an oversight of the previous excavations. In the southwest corner of sector I3 and at the level of the foundation of the later wall, two intact architectural members from the Throne building were found, part of an entablature and a threshold, which were transported to the area where the architectural material is gathered. 
In order to unify the areas in which the two most significant buildings of the Sanctuary stood, the Throne and the Altar, as well as to continue the investigation of the hill top, the excavation was extended in sectors $\mathrm{H}-\Theta 3$ and Z-H4 (see map 1). After the modern fill was removed, approx. $0.20 \mathrm{~m}$ thick, the same compact layer of pebbles was revealed here too, with no traces of the foundation of any construction.

In order to locate parts of the recently-found earlier Peribolos — retaining wall—of rude stones, as well as to answer questions regarding the dating of the already known Peribolos of big conglomerate blocks, the continuation of these walls was sought to the east, in sectors $\Gamma$ 8-10, $\Delta$ 9-10 (see map 1). Due to the nature of the terrain, that is the steep east slope of the hill, excavation was by no means easy. After the removal of the modern fill, the artificially levelled surface of the poros bedrock was revealed for a length of 25 $\mathrm{m}$ and a width of $15 \mathrm{~m}$.

The construction of the two Periboloi at the lower level of the hill should be linked with all the interventions made in Antiquity, in order to create terraces, which are connected with its similarly formed south side (fig. 5). The two terraces surrounding the hill in a semicircle from south and east to north are approx. $5 \mathrm{~m}$. wide and the maximum difference in height is $2 \mathrm{~m}$. On the lower is the foundation of the later Peribolos with conglomerate blocks. Along the upper terrace ran a shallow ditch, $0.40 \mathrm{~m}$. wide and $0.17 \mathrm{~m}$. deep, from where a thin layer of yellowish grey clayey soil was removed, along with a large quantity of Early Helladic pottery and one intact, two-handled cup of the same period. The remaining excavated area was covered by a layer of contemporary fill, with characteristic sherds of Late Geometric pottery decorated with representations of human figures, a fragment of an Archaic cup with incised letters, an Archaic bas-relief ivory leg of a male figure with greave and holes for its attachment to a wooden surface, terracotta figurines of animals and other objects.

On the northwest part of the hill, in sectors N3-4, investigation of the remains of Late Antique constructions revealed in the years of 2008-2009 continued. The destruction layer, approximately $0.20 \mathrm{~m}$ thick, with a host of fragments of roof tiles and some sherds of undecorated pottery, was removed from the west part of sector N4. The revealed remains can be attributed to two buildings of unspecified shape and different chronological periods. What appears to be the earlier one, which is totally covered by the destruction layer, is founded on the bedrock of the hill. Indeed, it seems that it extended more to the west of the wall that crosses sectors $\mathrm{N}-\Xi 4$ from south to north as central axis. During works in sector $\Xi 4$, in 2009 , part of the north section of the excavated building and the wall had appeared, on the bedding surface of which sporadic traces of hydraulic plaster were preserved. Above the destruction layer, a floor was uncovered with square terracotta tiles and lime plaster, which must be related to the small, brick-built rectangular cistern and the drain in sector $\Xi 4$. This floor appears to belong to a second building, which extends into sectors $N-\Xi 4-5$ and which, according to the inscribed herm of early 4th century AD found incorporated in the drain, is dated after the mid-4th century AD. On present evidence, such as the hydraulic plaster, the floor with terracotta tiles and the brick-built cistern with the drain, it may be assumed that there were water-collecting installations in this area in Late Antiquity.

Directly westward in sector N3, a tomb was revealed, comprising two chambers of dimensions $2.00 \mathrm{~m} \times 1.30 \mathrm{~m}$ and approximately $0.70 \mathrm{~m}$ deep, the outline of which had already appeared in 2009. In the lower part of its walls is a zone of medium-size and large rude stones, $0.40 \mathrm{~m}$ high, above which are successive courses of bricks, stone slabs and lime plaster. This last material has also been used to cover the whole surface of the floor. Dark soft soil mixed with small and big stones, crumbled bones and many fragments of roof tiles were removed from the interior of the tomb, confirming that it had been excavated in the past.

During 2010, the mending of fragments from architectural members of the Throne (orthostat, cornice sima) continued both at the archaeological site and in the storerooms of the 5th EPCA. The aim of this work was to restore the structural independence of the monument's components. Titanium coils of different thickness were used, along with white cement (Portland type) and fine-grained quartz sand, while, wherever necessary, some plaster casts were made in order to complete the missing parts with new marble.

In addition, one stone from the circular stepped Altar was restored partially with the necessary completion in new material and the two parts of the herm were joined, the lower part of which had been found in the 2008 excavations and the upper part was identified in the storeroom of the Sparta Archaeological Museum.

The test placements of architectural members in certain 


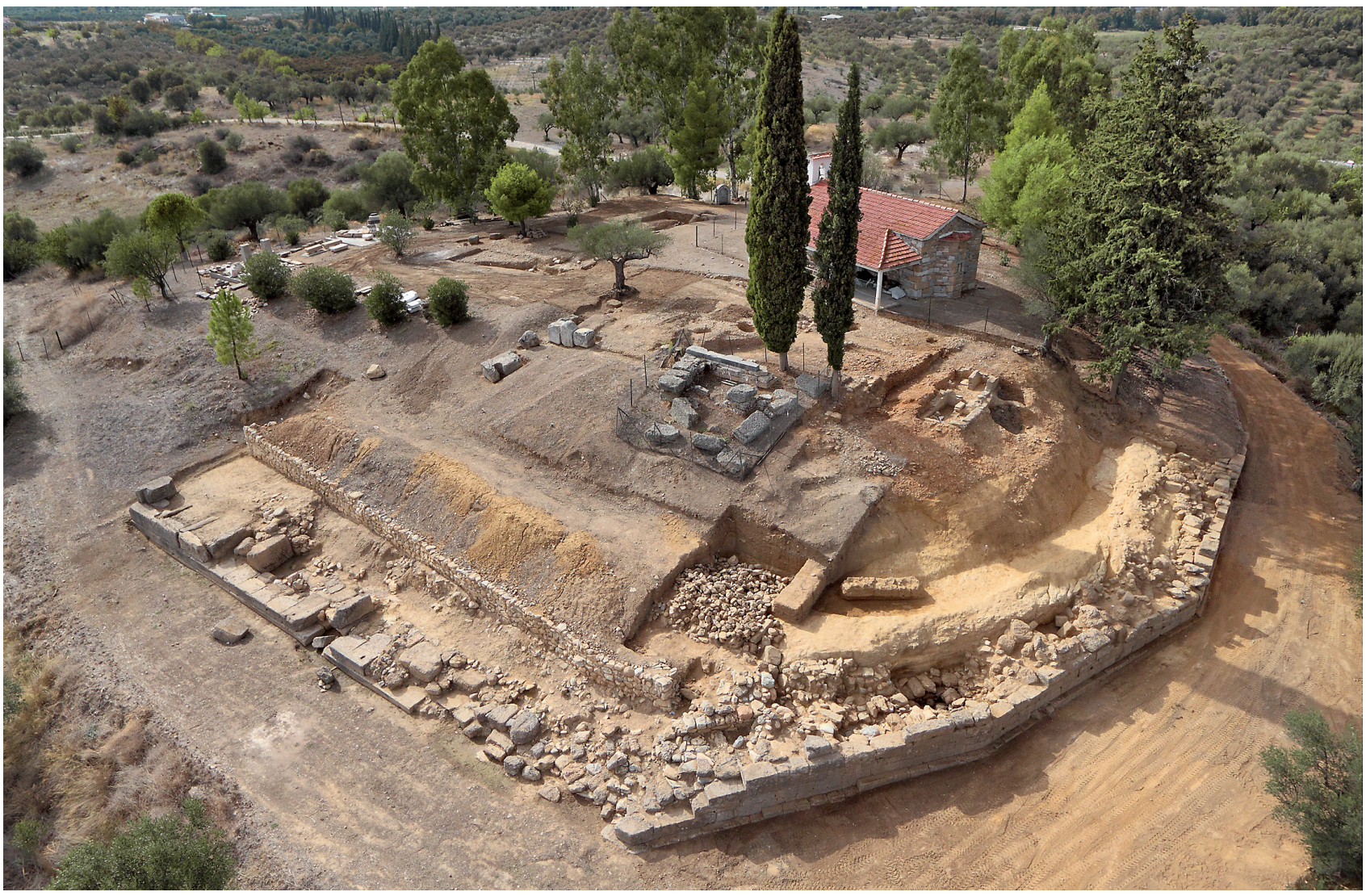

Fig. 5. The terraces at the SE corner of the hill (photo: K. Xenikakis).

groups from the structural elements of the Throne and Altar continued, to acertain what, among others, could be used for the suggestive enhancement of these monuments in the final configuration of the archaeological site. This work and the study of the relevant material yielded new data not only for the identification of scattered architectural members, but also for the representation of the monuments. In order to facilitate the works, two (2) flat platforms of dimensions $5 \mathrm{~m} \times 5 \mathrm{~m}$ were created in the site.

Gathered on one platform was material that constituted the temple/Throne (fig. 6). Placed on the same platform were stones from an entrance, from the steps of a stylobate with the contiguous internal floor, and from a wall with its eythynteria. The restoration of a wall entablature comprising numerous stones, most probably from the east wall of the Throne, took place in the storeroom of the 5 th EPCA. In order to correlate the walls and the colonnades of the Throne's wings (ptera), the traces from the contact of the small beams with the wall entablature and the cornices were detected, investigated and interpreted. This work will allow us to calculate the width of one of the wings of the Throne, as well as to proceed to the graphic restoration of at least one of the groups of small beams, for which we do not have the initial length. Gathered on the second platform and assembled in test placement were some of the correlated stones of the circular stepped altar (fig. 7).

Progress was made in the photographing, measured drawing and documenting of the architectural members incorporated in the fabric of the church of St Kyriaki, as well as of those in the Sparta Archaeological Museum and the storage of the 5th EPCA. The study of the conglomerate stones composing the niche of the earlier church of St Kyriaki continued. Indeed, the hypothesis that they might have initially constituted a continuous foundation in the internal structure of the Throne, for the bearing elements of its walls and the pedestal of the cult statue, is being investigated. These stones were scattered when the later buildings revealed in sectors $\Theta-\mathrm{I} 2$ and $\mathrm{N}-\Xi 3-6$ were 

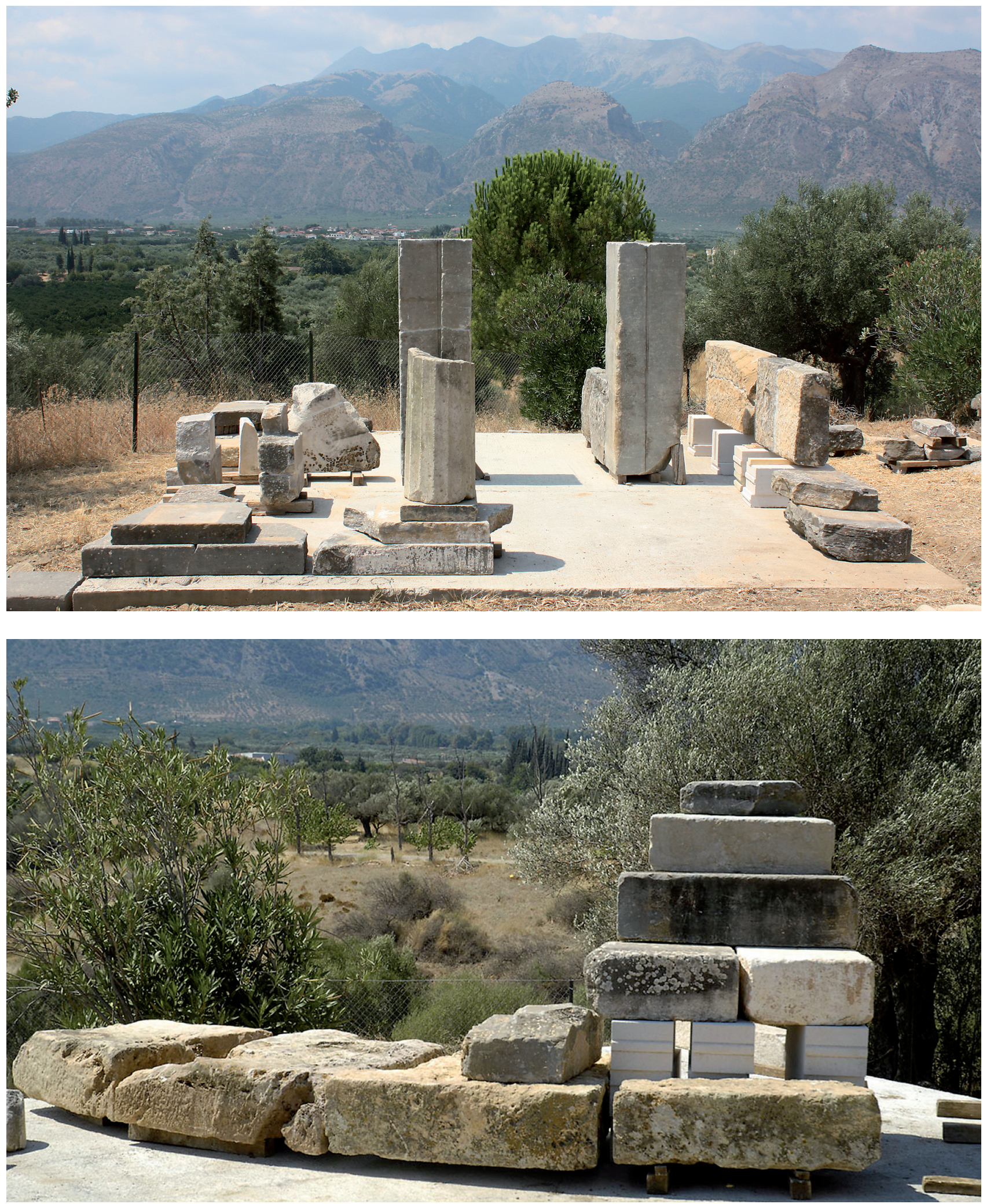

Fig. 6. The Throne-Platform (photo: St. Vlizos).

Fig. 7. The Altar-Platform (photo: St. Vlizos). 
constructed. Based on their difficult interpretation and the even more difficult interpretation and dating of the niche, some data may emerge on the destruction of the Throne and the pedestal of the cult statue.

For a more integrated mapping of the archaeological site and the works completed so far, the aerial photographing of Agia Kyriaki hill and the surrounding area was carried out by the photographer Kostas Xenikakis (see fig. 1).

In February 2010, the process of purchasing two proper- ties (fields), of total area 5 acres, was completed; these are adjacent to each other to the east of the site. Concurrently, all required actions for their transfer and donation through the 5th EPCA to the Ministry of Culture were completed, while the process of purchasing an area bordering the archaeological site to the west and south also began.

Stavros Vlizos

vlizosst@ionio.gr

\section{$\Sigma$ TAYPO $\Sigma$ B $\Lambda$ IZO $\Sigma$}

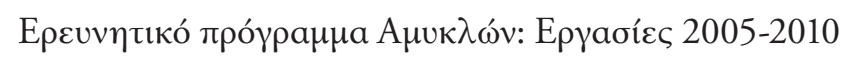

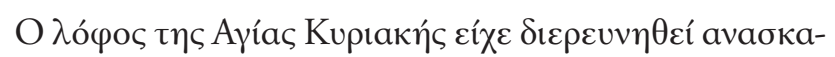

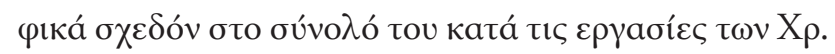

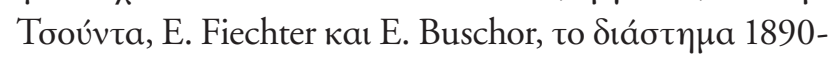

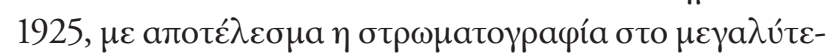

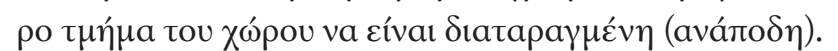

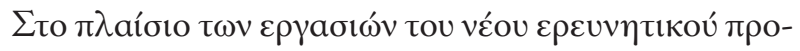

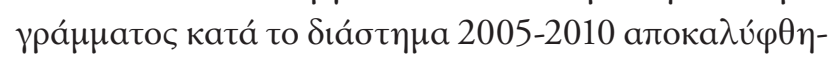

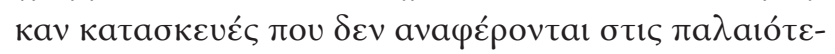

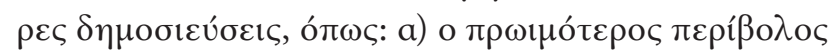

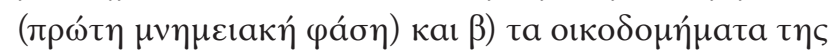

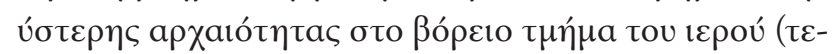

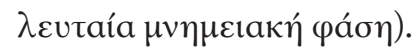

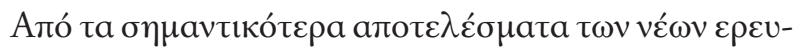

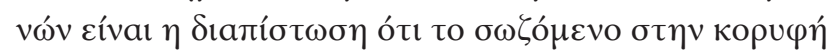

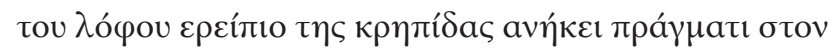

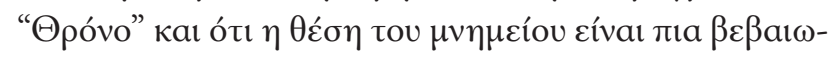

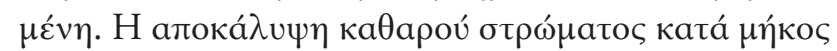

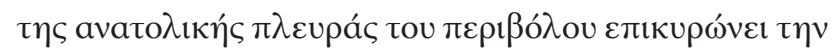

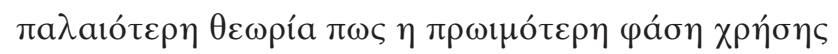
tov $\lambda$ ó

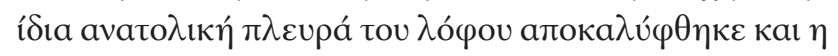

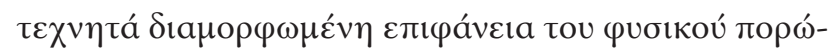

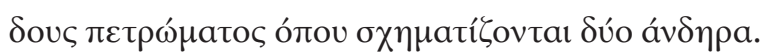

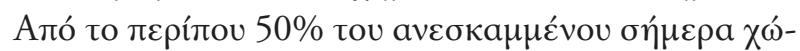

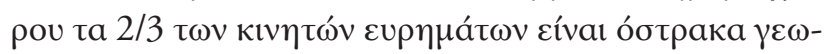

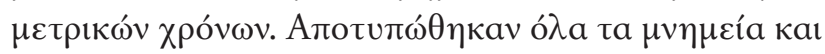

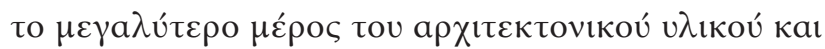

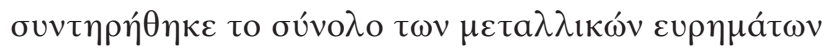

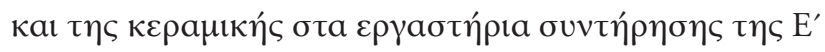

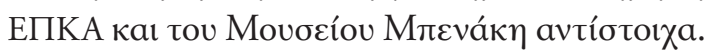

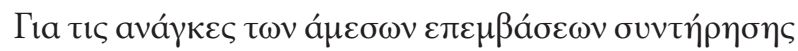

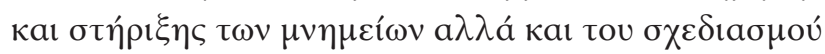

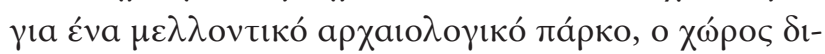

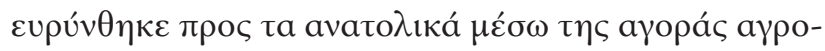

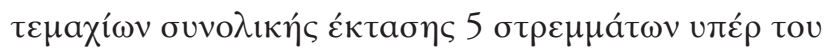

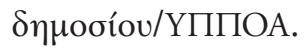

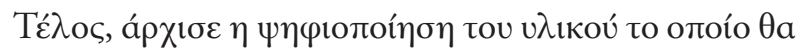

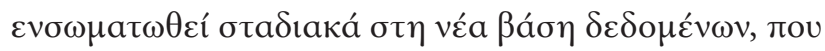

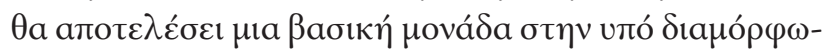

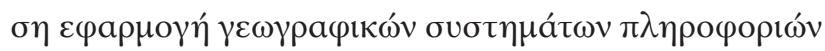

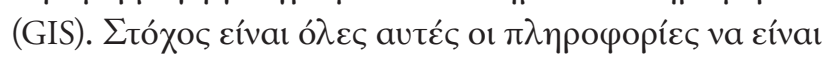

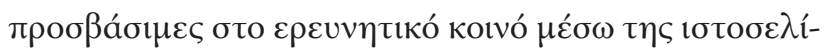

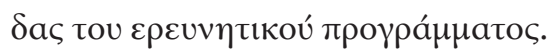


